\title{
Using Strategic Writing Techniques for Promoting EFL Writing Skills and Attitudes
}

\author{
Mohamed A. Okasha \\ English Language Center, Jazan University, Jazan, Saudi Arabia \\ Sami A. Hamdi \\ English Language Center, Jazan University, Jazan, Saudi Arabia
}

\begin{abstract}
The aim of the present study is to investigate the effectiveness of the strategic writing techniques for promoting EFL writing skills and changing passive attitudes towards writing into positive ones. The design of this study is pre-post, experimental-control group. The sample of this present study include Preparatory year Program students, Jazan University $(N=70)$. They were assigned into two groups: the experimental group $(\mathrm{N}=35)$ and the control group $(\mathrm{N}=35)$. The experimental group students were taught using strategic writing techniques, while the control group did not receive any training except the followed method. The instruments of the present study include a writing test and a rubric for correcting it prepared by the researchers and judged by the jury members. The writing test was applied on the study sample before and after the implementation. Results of the study revealed that EFL writing skills and attitudes improved among experimental group students as a result of using strategic writing techniques.
\end{abstract}

Index Terms — writing skill, attitude, EFL, strategic writing

\section{INTRODUCTION}

Struggling writers are facing writing problems. These problems are strategic that need strategic writing techniques to be solved. Students with writing problems are not very thoughtful or are not going to a specific plan. They approach writing as if it involves a single process - content generation. Paradoxically, their papers are impoverished in terms of content, vocab., organization, conventions and purpose. The preceding EFL writing skills need to be perfect. The impoverished writing of struggling writers is in part a strategic problem because they have difficulty gaining access to the knowledge they do have. Strategic writers are those who are able to use writing strategies in different writing situations or those who are able to change writing strategies from theoretical part into practical one (Abdel-Hack, 2002).

Writing is one of the most important skills in teaching English as a foreign language. It reflects the power of students in mastering writing techniques, so the students need to be aware of writing as a process and as a product as well. Learning writing also includes the learning of writing skills, rules and conventions. As a result, students should not only know these tactics but also know how to manage and control them. The main purpose of strategic writing instruction is that learning to write includes the learning of mental procedures to produce writing and to control the production of writing (Calhoun \& Hale, 2003). Research indicates that effective or expert writers are strategic. This means that writers have purposes for their writing and adjust their writing to each purpose and for each writing task. Strategic writers use a variety of strategies and skills as they construct paragraphs (Buhrke, Henkels, Klene, \& fister, 2002). A strategy is a plan selected deliberately by the writer to accomplish a particular goal or to complete a given task (El-Koumy, 1991). The goal of all writing instruction is to help students become expert writers so that they can achieve independence autonomy in their writing. Learning to use writing strategies effectively is essential in this research for constructing meaning in students' writing and as a trial to change students' passive attitudes towards writing into a positive one.

Many EFL students find writing the most difficult area of language. In the mean time, teachers also find it hard to assist students in producing pieces of quality academic writing (Abdel-Hack, 2002). The underlying reason can be drawn from a number of factors, for instance, the inherent complexity of the skill, students' limited knowledge of the topic, insufficient practice and inadequate feedback (Anwar, 2000). Additionally, studies of language teaching tend to focus mainly on accuracy and correctness of grammar and writing mechanics (Calhoun, \& Hale, 2003). Phinney (1991) stated that second language writers are often assumed to have negative attitudes and apprehension towards writing than first language writers. Students are seldom given feedback on their writing in English language, or the opportunity to revise their pieces of writing. The usual practice is to correct the grammatical errors. In addition, the teacher is the sole or the primary audience for students' writing. Forsyt (2003) indicated that the cause of the weak writing skills includes the poor attitudes that students exhibit towards writing. Students often view themselves as incompetent writers and thus a low level of engagement occurs in their writing. Kear (2000) verified that students move from a grade to another grade and their attitudes towards writing generally worsen. To enable students to write effectively, the researchers proposed this study as a kind of solution model to overcome writing difficulties and change students' attitudes towards writing. 


\section{WRITING STRATEGIES}

Writing strategies are ways of controlling writing process to produce well-organized production crystallized by high quality. These strategies are cognitive and meta- cognitive procedures used to control the production of written language and to solve problems while writing. Writers shouldn't be passive when doing a writing task; they should be able to use some writing strategies in a flexible way to be strategic writer. Strategic writing is the ability to monitor and adjust writing during writing process. Writers who are not strategic often encounter difficulties in their writing (ElKoumy, 1991).Calhoun \& Hale, (2003) indicate that strategic writing is a thinking procedure for producing writing (cognition) or for controlling production (metacognition).Consequently, strategic writing is a link between cognitive and met- cognitive; that is to associate knowledge with thinking. Strategic writing techniques show writers how to discover their own ideas in a strategic method. The strategy requires an ability to conceive the future and create possibilities. A successful strategy is a mental discipline consisting of broad ranging, flexible and creative thinking.

\section{TYPES OF STRATEGIC KNOWLEDGE FOR STRATEGIC WRITING}

There are three types of strategic knowledge needed for strategic writing. Declarative type is knowledge about what writing is and about structures, rules and conventions. One important aspect of strategic writing instruction is that it doesn't only stop at knowledge but also the procedural and conditional knowledge as well (Calhoun \& Hale, 2003). Procedural knowledge is the awareness of how to transform a passive construction into an active one. Conditional knowledge means knowing when it is wise to do that. These latter two types of strategic knowledge actually come from using this knowledge to avoid passive construction while writing or revising. Students as writers should be able to distinguish between passive and active knowledge as well as applying the distinction between them in writing. They should make use of this knowledge in writing strategically. They should know how to monitor and control writing process. In this study, strategic techniques will be taught via instruction and practice.

\section{TEACHING StRategic Writing}

The interactive nature of strategic writing is viewed in its main pedagogical feature. Strategies are not learned best by reading textbooks or by listening to teachers. The strategy must address a real concern and be constructed over time with diminishing amounts of teacher assistance and increasing amounts of students' self-control (Calhoun, \& Hale, 2003). To this end, the researchers recommend a four step instructional process which students are familiar with. These steps are as follows:

1. Identifying strategy worth teaching.

2. Introducing the strategy by modeling it.

3. Helping the students to try the strategy with assistance.

4. Helping the students work toward independent mastery of the strategy through repeated practice and reinforcement.

The researchers make use of these steps in a strategic writing workshop to clarify and illustrate how they can be used. In step one, identifying strategies worth teaching means looking for strategies that are most likely helpful for students who are known as struggling writers. Using such strategies may help students overcome their writing difficulties via talking to those students about their fears of writing and how to overcome these fears, knowing their weakness in writing and trying to treat this weakness. Step two, introducing strategies by modeling them means speaking about thoughts while writing, calling a particular attention to the intended strategy asking students to compose a similar piece of writing in connection with the writing the teacher is doing. Step three; helping students to try a writing strategy with teacher assistance is best done in a writing workshop environment. Writing may be in the form of pair work-teamworkindividual work and some amount of it should be done with teachers' assistance as it is necessary to make sure that writers practice using the strategy being taught. Step four, helping students to write independently through repeated practices and reinforcement means giving students opportunities to strategy many times with describing amounts of writing strategies (Jin\& Kalhlen, 1997).

\section{Choosing Strategies for Teaching Strategic Writing}

Out of the researchers' reading in the field of strategic writing to a lot of authors, they select some strategic techniques to improve students' writing and their attitudes towards writing. The chosen writing strategies are as follows:

\section{A. Stop Strategy}

This strategy contains four steps abbreviated as stop; where "S" means suspending judgment and in this step students are encouraged to write more. Writing in this step is free writing without any kind of restriction. The second step which is taken from " $\mathrm{T}$ " refers to taking a side, in this stage; students decide and choose which ideas they should concentrate on. The third step is taken from "O" and refers to organizing ideas. In this stage, students try to put ideas according to their importance in constructing their paragraphs. The fourth step is taken from " $\mathrm{P}$ " and it means planning more as students write. In this stage, students modify, rectify and revise what they had written.

\section{B. Dare Strategy}


The DARE strategy comprises four steps; where "D" means developing a topic sentence. In this step, students are asked to focus on the first sentence to be clear and meaningful. In the second step "A" stands for adding supporting ideas. In this stage; students write sentences closely related to the main sentence. The "R" in the dare step stands for rejecting arguing with the other side. In this stage, students are asked not to focus on specific details. In the fourth step "E" refers to elaborating on each main idea.

\section{Story Writing Strategy}

This strategy contains the following items:

1 . Who is the main character; who else is in the story?

2. When does the story take place?

3. Where does the story take place?

4. What does the main character want to do?

5. What do the other characters want to do?

6. What happens when the main character tries to do it; what happens with the other characters?

7. How does the story end?

\section{Star Strategy}

This strategy contains four steps abbreviated as STAR; where "S" means substitution. In this step, students are asked to substitute overused words, weak verbs and weak adjectives. In the second step "T" stands for taking things out. In this stage; students delete unimportant and irrelevant information. In the third step "A" means add new information and description. The "R" in the fourth step means rearranging the sequence to produce a desired effect.

\section{Choosing Strategies for Teaching Strategic Writing}

The researchers made use of the above four mentioned strategies and proposed a new strategy to promote EFL writing skills and attitudes towards writing. This new strategic technique is called the Power strategy. This strategy contains the following steps:

1. "P" which stands for picking ideas. In this stage, students are asked to think of what they are writing and this stage is considered to be pre-writing stage then students write freely and then choose the most important ideas to write about.

2. "O" refers to organizing ideas. In this stage, students put their ideas into well-organized order according to the sequence and the importance of the ideas.

3. "W" stands for writing and this stage is the stage of actual writing to what had been arranged before.

4. "E" means evaluating what had been written according to a writing rubric see appendix (A).

5. "R" means re-examining and rereading what had been written to make sure of its quality.

The above mentioned strategy "power" dealt with writing as a process and a product as well. It focused on prewriting stage, writing stage and post writing stage besides producing high quality writing through re-examining and rereading. The techniques followed in this strategy are as follows:

1. Giving detailed information about the strategy to the students.

2. Modeling the strategy in front of students.

3. Helping students to follow the model in pair and team work

4. Independent performance, students work alone with slight help of the instructor.

\section{IMPLEMENTATION OF THE POWER STRATEGY}

There were writing workshops to carry out the above mentioned steps. The duration of the implementation of this strategy took two months.

\section{A. Tools of the Study}

The following tools have been developed to carry out this study:

1. An EFL writing skills list.

2. An EFL writing skills test.

3. A rubric for correcting the test (Appendix A).

4. An EFL writing attitude scale prepared by the researchers (Appendices B).

\section{B. Content of the Study}

The study provides students with rich inputs to help them master the writing skills through strategic writing techniques. These inputs are as follows:

1. Rewriting passages, dialogue exchange and written reports.

2. Brainstorming and conducting a brief class lesson on common errors.

3. Sentence expansion, individual conferences and whole class discussion.

4. Punctuating, Spelling and proofreading exercises.

C. The Experimental Design 
The present study followed the pre test-post-test experimental-control group.

\begin{tabular}{|l|l|l|}
\hline O1 & $X$ & 02 \\
01 & & 02 \\
\hline
\end{tabular}

$\mathrm{O} 1$ is the pre test

$\mathrm{X}$ is the treatment (Strategic writing techniques and chosen strategy)

$\mathrm{O} 2$ is the post test

As Table I shows below, it is clear that there are no significant differences at 0.01 between the mean scores of the experimental and control group students in the pre-test in each writing sub-skill. It can be concluded that both the experimental and control groups are homogenous and equivalent not only in overall EFL writing, but also in writing sub-skills: fluency, content, organization, vocabulary, grammar and structures and convention as shown in fig1 below.

TABLE I.

RESULTS OF T-TEST OF THE PRE-TEST OF THE EXPERIMENTAL AND CONTROL GROUPS IN EFL WRITING SUB-SKILLS.

\begin{tabular}{|l|l|l|l|l|l|l|}
\hline WRITING SUB-SKILLS & GROUP & $\mathrm{N}$ & MEAN & S.D & T-VALUE & SIG. \\
\hline FLUENCY & EXPERIMENTAL & 35 & 12.1111 & 4.4432 & -.085 & .932 \\
& CONTROL & 35 & 12.0278 & 3.8154 & & \\
\hline CONTENT & EXPERIMENTAL & 35 & 8.0278 & 2.2739 & -.243 & .808 \\
& CONTROL & 35 & 8.1667 & 2.5579 & & \\
\hline ORGANIZATION & EXPERIMENTAL & 35 & 9.2778 & 2.6034 & .184 & .855 \\
& CONTROL & 35 & 9.1667 & 2.5242 & & \\
\hline VOCABULARY & EXPERIMENTAL & 35 & 8.9722 & 3.1576 & .225 & .823 \\
& CONTROL & 35 & 8.8333 & 1.9494 & & \\
\hline GRAMMAR & EXPERIMENTAL & 35 & 6.2222 & 1.9140 & -.058 & .954 \\
& CONTROL & 35 & 6.2500 & 2.1297 & & \\
\hline CONVENTIONS & EXPERIMENTAL & 35 & 11.3889 & 2.8911 & -.362 & .718 \\
& CONTROL & 35 & 11.6667 & 3.5777 & & \\
\hline
\end{tabular}

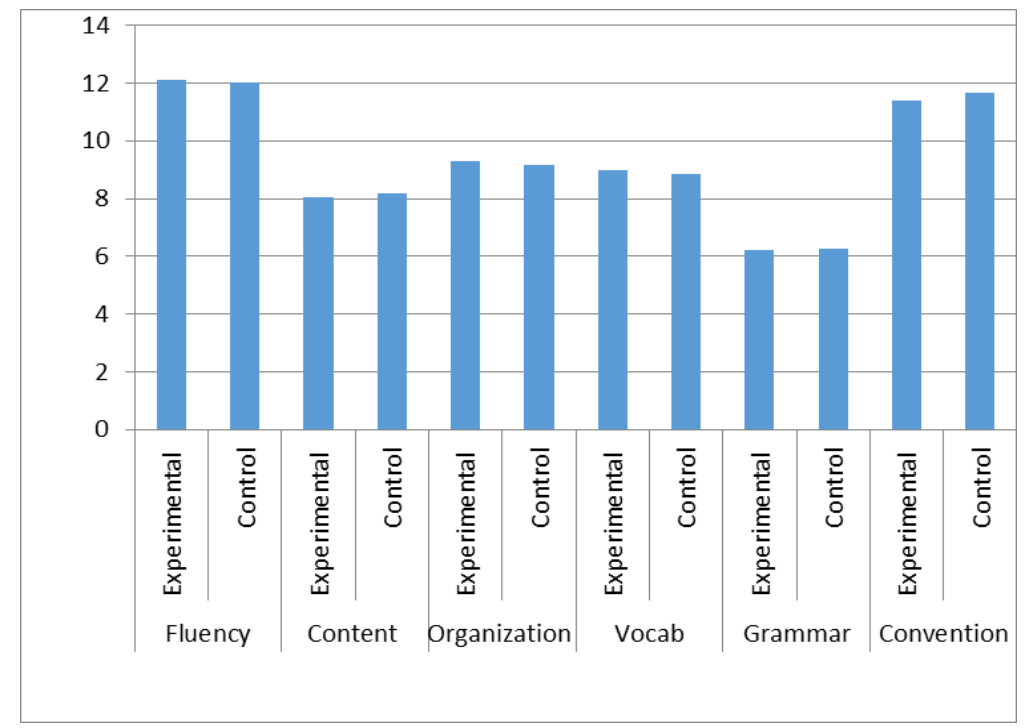

Figure 1. The mean scores of the experimental and control groups in the pre-test EFL writing

Table II below shows that there are no statistically significant differences at 0.01 between the experimental and control group students in the pre-test of all the components of attitudes towards writing in English language as indicated by t-value. Consequently, it can be concluded that both the experimental and control groups are homogenous in the pretest of the components of attitudes towards writing as shown in fig.2.

TABLE II.

RESULTS OF T-TEST OF THE PRE-TEST OF THE EXPERIMENTAL AND CONTROL GROUPS IN THE COMPONENTS OF ATTITUDES TOWARDS WRITING.

\begin{tabular}{|c|c|c|c|c|c|c|}
\hline COMPONENTS OF ATTITUDES TOWARDS WRITING & GROUP & $\mathrm{N}$ & MEAN & S.D & T-VALUE & SIG. \\
\hline DIFFICULTY OF WRITING & EXPERIMENTAL & 35 & 17.2000 & 3.9541 & -.817 & .661 \\
& CONTROL & 35 & 18.0857 & 5.0490 & & \\
\hline SELF-CONFIDENCE & EXPERIMENTAL & 35 & 11.9143 & 2.7157 & -.822 & .922 \\
& CONTROL & 35 & 12.4571 & 2.8111 & & \\
\hline WRITING INTEREST & EXPERIMENTAL & 35 & 7.7143 & 1.7417 & .270 & .846 \\
& CONTROL & 35 & 7.6000 & 1.8020 & & \\
\hline TEACHING METHOD & EXPERIMENTAL & 35 & 11.8857 & 2.1569 & 1.167 & .661 \\
\hline
\end{tabular}




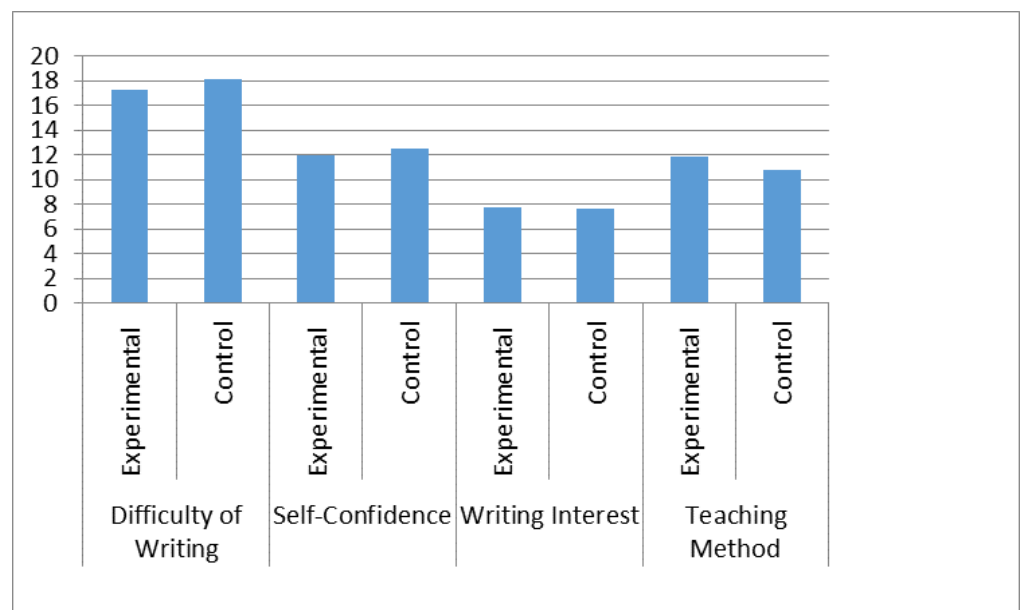

Figure 2. The mean scores of the experimental and control groups in the pre-test of attitudes towards writing

Table III illustrates results of the study after conducting the experiment using strategic writing techniques which shows that there are statistically significant differences in the mean scores of the experimental and control groups students in the post-test of all the sub-skills of EFL writing in favor of the experimental group as $t$-value for independent samples proved to be significant at 0.01 (one-tailed) for all sub-skills: fluency, content, organization, vocabulary, grammar and structures and conventions.

TABLE III.

RESULTS OF T-TEST OF THE POST-TEST OF THE EXPERIMENTAL AND CONTROL GROUPS IN EFL WRITING SUB-SKILLS.

\begin{tabular}{|c|c|c|c|c|c|c|}
\hline WRITING SUB-SKILLS & GROUP & $\mathrm{N}$ & MEAN & S.D. & T-VALUE & SIG. \\
\hline FLUENCY & $\begin{array}{l}\text { EXPERIMENTAL } \\
\text { CONTROL }\end{array}$ & $\begin{array}{l}35 \\
35\end{array}$ & $\begin{array}{l}29.1389 \\
21.8889\end{array}$ & $\begin{array}{l}4.2638 \\
5.6304\end{array}$ & 6.159 & 0.01 \\
\hline CONTENT & $\begin{array}{l}\text { EXPERIMENTAL } \\
\text { CONTROL }\end{array}$ & $\begin{array}{l}35 \\
35\end{array}$ & $\begin{array}{l}11.0833 \\
8.5833\end{array}$ & $\begin{array}{l}2.2725 \\
2.1027\end{array}$ & 4.845 & 0.01 \\
\hline ORGANIZATION & $\begin{array}{l}\text { EXPERIMENTAL } \\
\text { CONTROL }\end{array}$ & $\begin{array}{l}35 \\
35\end{array}$ & $\begin{array}{l}19.2222 \\
15.9167\end{array}$ & $\begin{array}{l}2.6845 \\
3.9015\end{array}$ & 4.188 & 0.01 \\
\hline VOCABULARY & $\begin{array}{l}\text { EXPERIMENTAL } \\
\text { CONTROL }\end{array}$ & $\begin{array}{l}35 \\
35\end{array}$ & $\begin{array}{l}19.2778 \\
15.9167\end{array}$ & $\begin{array}{l}2.6791 \\
3.9161\end{array}$ & 4.250 & 0.01 \\
\hline GRAMMAR & $\begin{array}{l}\text { EXPERIMENTAL } \\
\text { CONTROL }\end{array}$ & $\begin{array}{l}35 \\
35\end{array}$ & $\begin{array}{l}19.6667 \\
16.5833\end{array}$ & $\begin{array}{l}2.7150 \\
3.9452\end{array}$ & 3.863 & 0.01 \\
\hline CONVENTIONS & $\begin{array}{l}\text { EXPERIMENTAL } \\
\text { CONTROL }\end{array}$ & $\begin{array}{l}35 \\
35 \\
\end{array}$ & $\begin{array}{l}28.1389 \\
23.3889\end{array}$ & $\begin{array}{l}4.0719 \\
5.2551 \\
\end{array}$ & 4.287 & 0.01 \\
\hline
\end{tabular}

Table IV below reflects that there are statistically differences in the post test in self-confidence, writing interest, difficulty of writing, editing and teaching method. These differences are in favor of the experimental group and this can be attributed to the effect of the strategic writing techniques that the experimental group received.

The t-test results presented in table IV revealed statistically mean differences between the experimental and control group students in the post-test in favor of the experimental group in overall writing and in each writing sub-skill. Fig. 3 shows these differences:

TABLE IV.

RESULTS OF BOTH THE EXPERIMENTAL AND CONTROL GROUP STUDENTS IN THE POST-TEST OF EACH COMPONENT OF ATTITUDES TOWARDS WRITING

\begin{tabular}{|c|c|c|c|c|c|c|}
\hline COMPONENT OF ATTITUDES TOWARDS WRITING & GROUP & $\mathrm{N}$ & MEAN & S.D. & T-VALUE & SIG. \\
\hline THE DIFFICULTY OF WRITING & $\begin{array}{l}\text { EXPERIMENTAL } \\
\text { CONTROL }\end{array}$ & $\begin{array}{l}35 \\
35\end{array}$ & $\begin{array}{l}23.9714 \\
19.8857 \\
\end{array}$ & $\begin{array}{l}4.8354 \\
5.0630 \\
\end{array}$ & 3.453 & 0.01 \\
\hline SELF-CONFIDENCE & $\begin{array}{l}\text { EXPERIMENTAL } \\
\text { CONTROL }\end{array}$ & $\begin{array}{l}35 \\
35 \\
\end{array}$ & $\begin{array}{l}15.5143 \\
13.6000 \\
\end{array}$ & $\begin{array}{l}2.8260 \\
3.7354 \\
\end{array}$ & 2.494 & 0.01 \\
\hline WRITING INTEREST & $\begin{array}{l}\text { EXPERIMENTAL } \\
\text { CONTROL }\end{array}$ & $\begin{array}{l}35 \\
35 \\
\end{array}$ & $\begin{array}{l}9.1714 \\
7.9143 \\
\end{array}$ & $\begin{array}{l}1.4621 \\
1.8371 \\
\end{array}$ & 3.197 & 0.01 \\
\hline TEACHING METHOD & $\begin{array}{l}\text { EXPERIMENTAL } \\
\text { CONTROL }\end{array}$ & $\begin{array}{l}35 \\
35\end{array}$ & $\begin{array}{l}11.6857 \\
9.9714 \\
\end{array}$ & $\begin{array}{l}.1797 \\
2.6289 \\
\end{array}$ & 2.970 & 0.01 \\
\hline
\end{tabular}




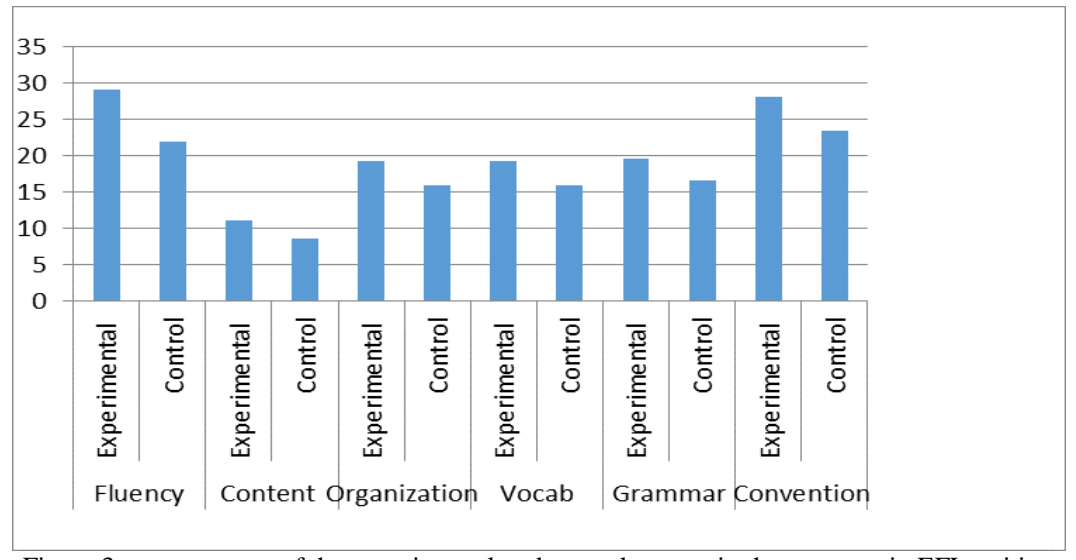

Figure 3. mean scores of the experimental and control groups in the post-test in EFL writing

\section{RECOMMENDATIONS OF THE STUDY}

1. Teachers should focus on teaching writing in English language as a process not as a product.

2. There is a need for using new techniques for providing feedback to students' EFL writing such as peer-review, writing conferences and self-correction.

3. Teaching can be made learner-centered, with more emphasis on the learning process

4. Interaction between the teacher-students and student-student creates co-operative, non-threatening and fear-free environment.

5. It is necessary to devote more time in the teaching schedule to teaching writing.

6. Students should be given the chance to take part in activities which strengthen their enthusiasm for writing in English language.

7. Students should be given the freedom to choose the topics they want to write about or topics in which they are interested and the topics should be more relevant to their daily life.

8. The teacher should deal with his students positively to give them the sense of liking the thing they are doing.

APPENDiX A. A Rubric FOR CORRECTING THE WRITING TEST

\begin{tabular}{|c|c|c|c|c|c|}
\hline $\begin{array}{l}\text { EFL WRITING } \\
\text { SKILLS }\end{array}$ & $\begin{array}{l}4 \\
\text { VERY GOOD }\end{array}$ & $\begin{array}{l}3 \\
\text { GOOD }\end{array}$ & $\begin{array}{l}2 \\
\text { AVERAGE }\end{array}$ & $\begin{array}{l}1 \\
\text { WEAK }\end{array}$ & $\begin{array}{l}\text { ZERO } \\
\text { VERY } \\
\text { WEAK }\end{array}$ \\
\hline 1- CONTENT & $\begin{array}{l}\text { WRITING IS CLEARLY } \\
\text { FOCUSED ON THE TOPIC. }\end{array}$ & $\begin{array}{l}\text { WRITING IS CLEARLY } \\
\text { FOCUSED ON THE TOPIC TO } \\
\text { SOME EXTENT }\end{array}$ & $\begin{array}{l}\text { IDEAS DON'T RELATE } \\
\text { TO THE TOPIC }\end{array}$ & $\begin{array}{l}\text { THE TOPIC IS NOT } \\
\text { CLEAR }\end{array}$ & $\begin{array}{l}\text { NO } \\
\text { WRITING }\end{array}$ \\
\hline $\begin{array}{l}\text { 2- } \\
\text { ORGANIZATION }\end{array}$ & $\begin{array}{l}\text { WRITING HAS A DEFINITE } \\
\text { BEGINNING, MIDDLE AND } \\
\text { END }\end{array}$ & $\begin{array}{l}\text { WRITING HAS A CLEAR } \\
\text { BEGGING , MIDDLE AND END } \\
\text { BUT SENTENCES NEED } \\
\text { FURTHER DEVELOPMENT }\end{array}$ & $\begin{array}{l}\text { WRITING HAS A } \\
\text { DEFINITE BEGINNING } \\
\text { TO SOME EXTENT BUT } \\
\text { THE END IS } \\
\text { INAPPROPRIATE }\end{array}$ & $\begin{array}{l}\text { WRITING HAS NO } \\
\text { DEFINITE } \\
\text { BEGINNING, } \\
\text { MIDDLE OR END. }\end{array}$ & $\begin{array}{l}\text { NO } \\
\text { WRITING }\end{array}$ \\
\hline 4- VOCABULARY & $\begin{array}{l}\text { LANGUAGE IS ACCURATE } \\
\text { AND THE DETAILS ARE } \\
\text { RELATED TO EACH OTHER. } \\
\text { THE WORD CHOICE IS } \\
\text { RELATED TO THE NATURE OF } \\
\text { THE TEXT. }\end{array}$ & $\begin{array}{l}\text { LANGUAGE IS ACCURATE } \\
\text { TO SOME EXTENT AND THE } \\
\text { READER CAN UNDERSTAND } \\
\text { AND SEES WHAT THE } \\
\text { STUDENT IS TRYING TO SAY. }\end{array}$ & $\begin{array}{l}\text { LANGUAGE DISTRACTS } \\
\text { THE READER TO GET } \\
\text { THE MEANING. }\end{array}$ & $\begin{array}{l}\text { LANGUAGE IS } \\
\text { UNCLEAR. THERE IS } \\
\text { NO ENRICHMENT } \\
\text { IN WORD CHOICE. }\end{array}$ & $\begin{array}{l}\text { NO } \\
\text { WRITING }\end{array}$ \\
\hline $\begin{array}{l}\text { 5- CONVENTIONS } \\
\text { (PUNCTUATION } \\
\text { CAPITALIZATION- } \\
\text { SPELLING ) }\end{array}$ & $\begin{array}{l}\text { MAKING ONE - TWO } \\
\text { ERRORS IN PUNCTUATION- } \\
\text { SPELLING AND } \\
\text { CAPITALIZATION }\end{array}$ & $\begin{array}{l}\text { MAKING THREE-FIVE } \\
\text { ERRORS IN PUNCTUATION } \\
\text { SPELLING AND } \\
\text { CAPITALIZATION }\end{array}$ & $\begin{array}{l}\text { MAKING SIX ERRORS } \\
\text { IN PUNCTUATION } \\
\text { SPELLING AND } \\
\text { CAPITALIZATION }\end{array}$ & $\begin{array}{l}\text { MAKING MORE } \\
\text { SEVEN THAN } \\
\text { ERRORS IN } \\
\text { PUNCTUATION }\end{array}$ & $\begin{array}{l}\text { NO } \\
\text { WRITING }\end{array}$ \\
\hline
\end{tabular}


Appendix B. The Modified EFL Writing AtTitude ScAle By the ReSEARCHERS

\begin{tabular}{|c|c|c|c|c|c|}
\hline ITEMS & $\begin{array}{l}\text { STRONGLY } \\
\text { AGREE }\end{array}$ & AGREE & $\begin{array}{l}\text { NOT } \\
\text { SURE }\end{array}$ & $\begin{array}{l}\text { NOT } \\
\text { AGREE }\end{array}$ & $\begin{array}{l}\text { STRONGLY } \\
\text { DISAGREE }\end{array}$ \\
\hline \multicolumn{6}{|l|}{$\begin{array}{l}\text { 1- I FIND DIFFICULTY IN ARRANGING MY IDEAS IN } \\
\text { WRITING. }\end{array}$} \\
\hline \multicolumn{6}{|l|}{ 2- I THINK MY WRITING IS GOOD. } \\
\hline \multicolumn{6}{|l|}{ 3-STARTING WRITING IS VERY DIFFICULT FOR ME. } \\
\hline \multicolumn{6}{|l|}{$\begin{array}{l}\text { 4-I TRY TO FIND EXCUSES TO AVOID WRITING IN } \\
\text { ENGLISH }\end{array}$} \\
\hline \multicolumn{6}{|l|}{$\begin{array}{l}\text { 5-IFIND MYSELF WRITING A SENTENCE, THEN ERASING } \\
\text { IT TRYING ANOTHER SENTENCE, AND THEN } \\
\text { SCRATCHING IT OUT. I MIGHT DO IT FOR SOME TIME. }\end{array}$} \\
\hline \multicolumn{6}{|l|}{$\begin{array}{l}\text { 6- I TAKE MUCH TIME TO THINK OF ANY SENTENCE } \\
\text { BEFORE WRITING IT. }\end{array}$} \\
\hline \multicolumn{6}{|l|}{ 7- I ENJOY WRITING IN ENGLISH. } \\
\hline \multicolumn{6}{|l|}{$\begin{array}{l}\text { 8- I THINK MY TEACHER IS REACTING POSITIVELY TO } \\
\text { MY WRITING. }\end{array}$} \\
\hline \multicolumn{6}{|l|}{$\begin{array}{l}\text { 9-WRITING TOPICS THAT CAN HAVE MORE THAN ONE } \\
\text { IDEA IS DIFFICULT FOR ME. }\end{array}$} \\
\hline \multicolumn{6}{|l|}{$\begin{array}{l}\text { 10-TOPICS OF COMPARISON OR ANALYSIS TROUBLE } \\
\text { ME. }\end{array}$} \\
\hline \multicolumn{6}{|l|}{$\begin{array}{l}\text { 11- I LIKE TO EXPRESS MY IDEAS IN WRITING NOT } \\
\text { ORALLY. }\end{array}$} \\
\hline \multicolumn{6}{|l|}{$\begin{array}{l}\text { 12-WRITING COMMENTS ON THE ARTICLES OF THE } \\
\text { STUDENT'S BOOK IS DIFFICULT. }\end{array}$} \\
\hline $\begin{array}{l}\text { 13- I HAVE SEEN REALLY GOOD WRITING BUT MY } \\
\text { WRITING IS NOT GOOD IN COMPARISON. }\end{array}$ & & & & & \\
\hline
\end{tabular}

\section{REFERENCES}

[1] Abdel-Hack, Iman Mohamed (2002). The effectiveness of a task-based learning approach on EFL students' writing production. Occasional papers in the Language Education Center for Developing of English Language Teaching "CDELT", no.34, $193-231$.

[2] Anwar,Iman Zaki (2000).The effect of using peer review groups in teaching essay writing to fourth year English majors, Faculty of Education, on their writing performance, apprehension, revising and attitudes. Journal of Research in Education and Psychology (Issued by: faculty of Education, Minia University), 14(1), 94-129.

[3] Buhrke, L.; Henkels, L; Klene, J. \& fister, H. (2002). Improving fourth grade students' writing skills and attitudes. M.A. Action Research Project. Saint Xavier University and Skylight Professional Development Field-Based Master's Programs. Retrieved from: IRISSkylight Field-Based Master's Program.

[4] Calhoun, S. \& Hale, J. (2003). Improving students writing through different writing styles. M.A. Action Research Project .Saint Xavier University and Skylight Professional Development Field-Based Master's Program. Retrieved from IRISSkylight FieldBased Master's Program.

[5] El-Koumy, Abdel-Salam. (1991). Comparing the effectiveness of three strategies to teaching composition: Guided, free and guided-Free. Unpublished P.H.D. thesis. Faculty of Education, Menoufia University.

[6] Forsyth, D. (2003). Our Social World. http://www. alleydog.com/glossaryldefinition.cfm?terms-Attitudes/ (accessed 29/2/2008).

[7] Jin \& Kalhlen. (1997). "Strategic Writing Instruction. State University of New York.

[8] Kear, M. (2000). Effects of Guided Journal Writing on Students' Story Understanding. The Journal of Educational Research, Vol.95\3,pp.179-191.

[9] Phinney, Marianne. (1991). Word Processing and Writing Apprehension in First and Second Language Writers. Journal of Computer and Composition, Vol.11\1, PP.65-82. http://www.hu.edulcandclarchiveslv9 9-1-5-phinney.html. (accessed 29/2/2008).

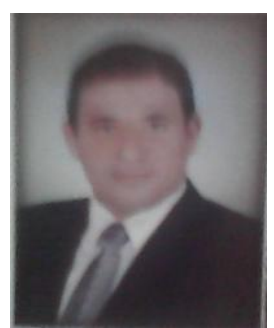

Mohamed A. Okasha was born in Egypt. He holds a B.A in Education from. Alex. University,1995. He also, received his master degree in English Teaching Methodology from the University of Tanta, Kafer El-Sheihk branch in 2004. He received his PhD in 2011 in English Teaching Methodology from the University of Banha, Egypt. Currently, he is assistant prof. at Jazan University, Saudi Arabia.

Mr. Okasha has published research papers and he is mainly interested in creative writing and strategic writing as well as teaching writing skill to EFL learners. He has a long experience in teaching English to high school students and University students. He is engaged in several committees of research affairs and EFL curriculum development and assessment. 


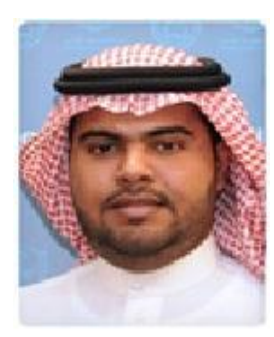

Sami A. Hamdi was born in Saudi Arabia. He holds a master degree in linguistics (2012) from Imam Muhammed Ibn Saud Islamic University, Saudi Arabia. He also received his bachelors on English from King Saud University in 2009, Riyadh, Saudi Arabia.

He worked as a translator \& later as a manager of technical cooperation \& foreign relations department at the atomic energy research institute at (kacst) King Abdelazia City for Science and Technology. He also worked as assistant of the director of SAGIA (Saudi Arabian General Investment Authority) investment platform. He worked in King Saud University as Supervisor of CoEIA (Center of Excellence in Information Assurance) admin research affairs. He is now The General Coordinator of English Language Programs of Preparatory year Programs at Jazan University.

Mr. Hamdi is interested in the study of language in terms of learning, acquisition, and computational processing. Mr. Hamdi has published various papers in international conferences and journals. He has been awarded best paper awards ( 2 times consecutively) during his MA. Study. He has worked on research projects \& participated in organizing scientific events. 